IRSH 48 (2003), Supplement, pp. 45-7I DOI: I0.10I7/So02085900300I 263

(C) 2003 Internationaal Instituut voor Sociale Geschiedenis

\title{
India's First Virtual Community and the Telegraph General Strike of 1908*
}

\author{
DeEP Kanta LAhiri Choudhury
}

The telegraph strike of 1908 occurred at many nodes of the telegraph system in British India and Burma, paralysing governance and business. In this paper, I suggest that the strike was a symptom of the systemic crisis in world telegraphy faced with technological change and competition. I introduce the category of transregional economic general strike as a tool to analyse strikes in the communication sectors. The strike demonstrated the ability of one of the earliest virtual communities in India to combine and organize worker protest. This multistage strike momentarily transcended the specific, and usually rigid, distinctions of race, class, and ethnicity through the production of community-at-a-distance. The strike occurred simultaneously among different sections of workers in Rangoon, Moulmein, Calcutta, Allahabad, Agra, Bombay, Madras, Lahore, and Karachi, to name just a few of the places involved. Both telegraph signallers as well as the subordinate staff went on strike. By concentrating on the relationship between technological change and labour, the paper demonstrates how workers across this part of the British Empire were capable of charting a general agenda in the first decade of the twentieth century, using technology to combine and combat technological rationalization.

Previous historiography on Indian labour either subsumed the telegraph strike of 1908 within the nationalist narrative of political unrest under the swadeshi and boycott ${ }^{\mathrm{I}}$ movement, or ignored strikes in the communications sector by various classes of workers. ${ }^{2}$ Studies began from the r 880 s and characterized the period I880-1919 as the "prehistory" of labour mobilization in India and as the period of the emergence of "community

\footnotetext{
* I am grateful to the editors for their comments and suggestions. This paper is a part of the chapter on the strike in my Ph.D thesis, completed under the supervision of C.A. Bayly, University of Cambridge.

I. Swadesh means one's own country. The swadeshi and boycott movement in India 1905-191 2, echoed the boycott of foreign goods in China and Ireland, and envisaged the promotion of indigenous industry by the promotion of swadeshi enterprise.

2. Work has been done on the railways, for example by I.J. Kerr, who looks at the labour employed in constructing the railways: Building the Railways of the Raj I850-1900 (Delhi [etc.], 1997).
} 


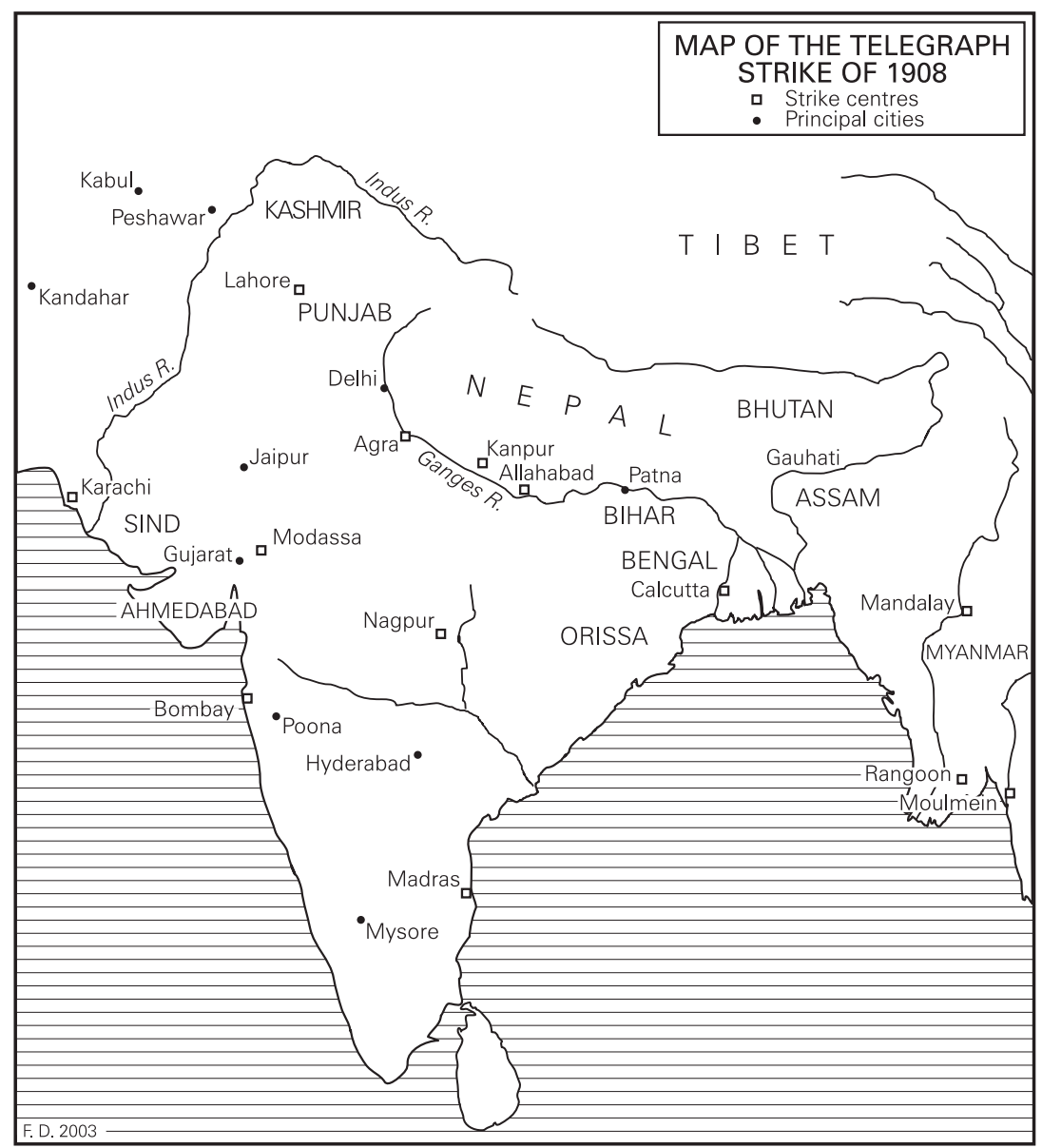

Figure I. Map of the Telegraph Strike of 1908

consciousness" within Indian labour. ${ }^{3}$ This labour historiography, reminiscent of the Wisconsin School, ${ }^{4}$ studied working-class formation without considering the kinds of opposition shaping their experience. The study of relatively underdeveloped agro-economic sectors, and the

3. For example, G.K. Sharma, Labour Movement in India (Delhi, I97I); P. Saha, Bangla Sramik Andoloner Itihas (Calcutta, 1972); S. Sarkar, The Swadeshi Movement in Bengal 1903-1908 (Delhi, 1973). The argument regarding community-consciousness, as opposed to classconsciousness, was made by D. Chakrabarty, "Communal Riots and Labour: Bengal's Jute Mill-Hands in the I890s", Past and Present, 9I (1981), pp. I40-169. For a critique, see Subho Basu, "Strikes and 'Communal' Riots in Calcutta in the I89os", Modern Asian Studies, 32 (1998), pp. 949-983.

4. C. Craypo, "Introduction", Labour Studies Journal, 3 (1979) (special issue: The Impact on Labour of Changing Corporate Structure and Technology), pp. 195-200, 196. 
concentration on particular localities led to an argument about the peculiarity and community consciousness of Indian labour: labour in these sectors reflected the colonial forms of industry in which they were situated. This paper, by studying protest in one of the core sectors of industrial communication technology, questions this topology. Class solidarities in the telegraph strike were formed directly through the communication system, in contrast with the more inchoate, mediated, and nationalized identities theorized in the work of Marx and Benedict

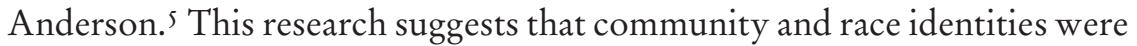
not inherent but hardened through the experience of working-class action and the different ways in which the colonial state responded to it. ${ }^{6}$

In the United States, work concentrated on telegraphy's impact on economic and organizational aspects, especially business history. Accounts from Blondheim to Lubrano celebrated the emerging national unity brought about by the telegraph, ${ }^{7}$ while others noticed the conflict between democratic values and centralizing tendencies. ${ }^{8}$ Though rightly celebrating the nation-building aspects of the telegraph, some of the work has relatively neglected the points of conflict and difference. Authors used telegraph workers to engage with labour historiography, bureaucratization, and unionization. ${ }^{9}$ Recent work has engaged with telegraph workers not as illustrators of labour union history but discussed them in light of their position within the industry and communication networks. ${ }^{10} \mathrm{How}-$ ever, while accepting the notion of successive and competing communication technologies as technologically deterministic, the cooperation between railways, telephone, and telegraphs can be exaggerated. There was indeed considerable overlap, especially in terms of personnel, but there was also intense competition: the issue was not one of physical succession but that of hegemony. Though enthusiastic about the telegraph transforming communication in the United States and serving to "centralize, even

5. Karl Marx, “The Future Results of British Rule in India”, New York Daily Tribune, 8 August I853, in Marx and Engels, Collected Works, vol. I2, p. 217; Benedict Anderson, Imagined Communities: An Inquiry into the Origins of Nations (London, I991, rev. edn).

6. Cf. R. Chandavarkar, The Origins of Industrial Capitalism in India: Business Strategies and the Working Classes in Bombay, 1900-1940 (Cambridge, 1994).

7. K.G. Garbade and W.L. Silber, "Technology, Communication and Performance of Financial Markets 1840-1975", The Journal of Finance, 33 (1978), pp. 819-832; Annteresa Lubrano, The Telegraph: How Technology Innovation Caused Social Change (New York [etc.], I997).

8. L.G. Lindley, The Impact of Telegraph on Contract Law (New York and London, I990); R.B. DuBoff, "The Telegraph and the Structure of Markets in the United States, I845-I890", Research in Economic History, 8 (1983), pp. 253-277.

9. See, for Britain, A. Clinton, Post Office Workers: A Trade Union and Social History (London, 1984); C.R. Perry, The Victorian Post Office: The Growth of a Bureaucracy (London, 1992); Edwin Gabler, The American Telegrapher: A Social History, I860-1900 (New Brunswick, NJ [etc.], I988).

ı०. Gregory J. Downey, Telegraph Messenger Boys: Labor, Technology, and Geography, I850I950 (New York [etc.], 2002). 
nationalize, information", energizing the entire nation with one idea and one feeling, Blondheim showed how the extension of information monopoly and centralization, in the short term, exaggerated difference and dissension. While the Western Union and the Associated Press emerged as the twin pillars of information circulation in the United States, the nation engaged in bitter civil strife. ${ }^{\text {II }}$ He noted that "Americans had no inkling that an American Reuter existed", and were unaware of the monopolies over information transmission, distribution, and circulation. ${ }^{12}$ This paper qualifies the linearity inherent in the celeberation of the benefits of technological progress to point out the fragility of technology and the identities forged through it.

\section{THE IMPORTANCE OF INDIA IN THE WORLD TELEGRAPH NETWORK}

Over the period I 860 to I900, the Indian Empire emerged as a crucial strategic element in the telegraph network of the world. The British Indian Empire included present-day Myanmar, Sri Lanka, Bangladesh, Pakistan, and parts of Iran (Persia), and Afghanistan. It also included the broader sphere of British Indian "informal empire" in the Persian Gulf, southern Arabia, the Indian Ocean, and the Bay of Bengal. By 1875, India was the main overland link between the West, and both the Far East and Australasia. The private corporate giant, the Eastern Cable Company, was vulnerable in India because it did not control the landlines from Bombay to Madras, from which its near-monopoly stretched to Penang and Australasia. The Indian Telegraph Department controlled this relatively short connection while it ran the lines through the breadth of India from Karachi to Rangoon. After Karachi, the Indo-European Telegraph Department of the government of India managed the lines to Tehran.

Like the Western Union and Associated Press monopolies in the US, Reuters had a national and international news monopoly that combined with the Eastern Group of submarine companies, which controlled most of the eastern traffic in the British Empire. Though the Indian Telegraph Department controlled the overland link between Bombay and Madras, it had little say in the distribution of traffic from London to the East. ${ }^{13}$

I I. Menahem Blondheim, News over the Wires: The Telegraph and the Flow of Public Information in America, I844-I 897 (Cambridge, MA [etc.], I994), p. I92.

I2. Ibid., p. I95.

I3. Government of India [hereafter GoI], Public Works Department [hereafter PWD], Civil Works Telegraph [hereafter CWT] (A) Proceedings, May i 875, nos i 5-17. Further correspondence regarding the proposed extension of telegraphic communication to the Andamans, no. I6, from Major J.U. Bateman-Champain, Director, Indo-European Telegraph Department [hereafter IETD], no. 440, 8 December I 874; National Archives of India, Delhi [hereafter NAI]. 
Indian telegraph policy was dominated by the notion that no reduction in the rates charged on internal traffic would be enough to generate an increase in volume sufficient to justify the initial loss of revenue for the department. As a result, rates within India froze at a comparatively prohibitive rate for the period I $865-$ I $885 .{ }^{14}$ In contrast, the transit rate to and from Europe continued to reduce during this time. The pattern of indigenous usage emerges from the great distances telegrams covered in India. In Europe telegrams often travelled between neighbouring towns. This was not true of India, where the bulk of the messages travelled between the greater trading centres, and between the producing districts of the interior and the seaboard. ${ }^{15}$

Most of the messages sent were on commercial business. The majority of Indians could not afford private telegrams and the arrival of one was perceived as calamitous, usually bringing tragic news. Indian business used the telegraph selectively, depending on whether the message had anything to do with international trade and prices. The government, media, and European-capital-dominated international business were the biggest users of the telegraph. For example, the Indian Telegraph Department handled I 0,382 highly subsidized press messages that paid revenue of only Rs 40,553 during $1882-1883 .{ }^{16}$ In short, Indian revenues subsidized international business and media telegrams. ${ }^{17}$

The inexorable decline in rates affected both international and internal systems, especially after 1885 , low rates becoming the norm after the Imperial Pacific Cable commenced operations in 1902. ${ }^{18}$ By I910, there were a total II million inland telegraphic messages. ${ }^{19}$ After I884, the decline of rates across telegraph systems in order to survive emerging competition externally, from the telephone and wireless, and internally, to combat state and cable competition, allowed expansion in indigenous communication. Greater national economic and political cohesion emerged in India after reduction of the rates charged for telegrams, especially press telegrams, within the country after 1904 .

There were two important concerns of the government of India

14. GOI, PWD, CWT(A) Proceedings, November I884, nos 5-9, no. 5, from Colonel J.U. Bateman-Champain RE, Director General [hereafter DG], IETD, to Secretary, GOI, PWD, no. 546,30 July i 884 ; NAI.

I . Administrative Report of the Indian Telegraph Department, I886-I887 (Simla, I 888), p. I0; National Library, Calcutta [hereafter NL].

I6. Annual Report of the Telegraph Department, I882-I883, p. 9; NL.

17. Cf. D.K. Lahiri Choudhury, "A Social and Political History of the Telegraphs in the Indian Empire, c. I850-1920", (unpublished Ph.D. dissertation, University of Cambridge, 2002).

I8. Hugh Barty-King, Girdle Round the Earth: The Story of Cable and Wireless and Its Predecessors to Mark the Group's Jubilee 1929-1979 (London, I979), pp. I38, I4I.

19. Hardinge Papers I I7, Correspondence with the Secretary of State for India, I9I I, no. 36, from Lord Hardinge, Viceroy, to the acting Secretary of State for India, Viscount Morley, Simla, with enclosures, I I May I9 I I; Cambridge University Library [hereafter CUL]. 
regarding information: there was a demand for information as well as a need to contain information. One of the main concerns of the government was to contain information and prevent media access to sensitive documents. The India Office and the government of India were under scrutiny by the Liberal government in Britain. This meant that the government of India had to exercise extra caution in its acts dealing with Indians and protect itself from charges of oriental despotism. Lord Curzon, as Viceroy, had initiated a series of reforms, and imported experts and appointed committees to implement them. This meant that the government was under scrutiny internally in India, and the public and the media waited to learn what the reports said. Finally, the Russo-Japanese War had increased the British government's fears of a pan-Asiatic revival and penetration and competition in India from Japan. The government threatened officials with penal proceedings for passing on secret information. The government also checked communications and association among its employees through the Official Secrets Act of March I904. Collective bargaining by government employees was prohibited. The international climate of workers' movements, unionization, and association among various classes of workers at this time contributed to the concerns of the government.

The government of India, shortly after the passing of the Official Secrets Act, cut its rates on international and national telegrams as well as the rates charged on international press telegrams. First, it needed to increase information flows to maintain its competitiveness in the international telegraph network dominated by the cable companies. The government wanted to increase revenue by cutting rates to increase the volume of business and square its rates with the falling cost of the individual telegram because of growing automation within the telegraph industry. Secondly, it was an attempt by the government to discover the currents of unrest that were suspected of flowing beneath the surface of indigenous society. Printing was encouraged and the cost of registration of newspapers decreased.

After 1904 a number of politically radical newspapers were published in different parts of Bengal, Maharashtra, and the Punjab. Charumibir, published in what was now, after Partition, called Eastern Bengal and Assam, was a typical paper that condensed Calcutta and local happenings, employed correspondents, and enjoyed a rapidly growing regional readership. These papers, using the opportunities given by cheaper information transmission, addressed local news and events, momentarily breaking the international and national information stranglehold of Reuters. A mix of government policy, itinerant preachers, revolutionary and extremist propaganda, famine, disease, and discontent were bringing together different strands and networks of discontent. These waves were occurring in a situation of famine in eastern India and the plague in western India, 
together with a sharp rise in the price index and in the general cost of living. ${ }^{20}$ The Durbar celebrations held by Lord Curzon commemorated, as a side event, the fiftieth anniversary of the victory of the British in the mutiny and uprisings of 1857 . This propaganda was mirrored in the countryside beyond the control of the government where a similarly celebratory rhetoric resurrected the spectre of i 857 . The government fell victim to these whisperings as much as it had helped generate them by its commemorations. Astrologers, revolutionaries, and government officials were now working on a common schedule in anticipation of an uprising around 1907-1908.

\section{THE TELEGRAPH AND THE STANDARDIZATION OF TIME}

Recent research on the telegraph in the US noted that telegraphy's "commercial success demonstrated that the economic value of a message depended not only on its content, point of origination, and point of destination, but also on the expected mean and variance of transmission time". ${ }^{21}$ In P.G. Wodehouse novels telegrams play a central role, symbolizing the speed of modern communications and the consequent rapidity of alarums and incursions:

Bertie: When you have brought the tea you had better go out and send him a telegram, telling him to come up by the next train.

Jeeves: I have already done so, sir. I took the liberty of writing the message and dispatching it by the lift attendant.

Bertie: By Jove, you think of everything Jeeves!

Jeeves: Thank you, sir. A little buttered toast with the tea? [...]

Rocky: [the recipient of the telegram] [...] when your telegram arrived I was just lying down for a quiet pipe, with a sense of absolute peace stealing over me. I had to get dressed and sprint two miles to catch the train. ${ }^{22}$

The telegraph impacted upon and changed lives in both tangible and intangible ways. Business transacted over vast distances through the telegraph needed centralized and standardized time instead of the prevailing freedom of local times. Though much has been written on what constitutes time and its meaning in sociology, anthropology, and geography, the actual historical minutae of the construction of time have been relatively neglected.

Early Indian texts explaining the telegraph lapsed into discussions of Western versus Eastern methods of reckoning time. Kalidas Maitra, in the

20. Sunanda Sen, Colonies and Empire: India I890-1914 (London, I992), Table 3.4: Council Bills and Telegraphic Transfers I $890-$ I913, p. 80.

21. A.J. Field, "The Magnetic Telegraph, Price and Quantity Data, and the New Management of Capital", The Journal of Economic History, 52 (1992), pp. 40I-4I 3, 403.

22. Sir Pelham Grenville Wodehouse, Carry on, Jeeves (Harmondsworth, I999, Ist edn 1925), pp. 104-105, 109. 
first book in Bengali on telegraphy, gave elaborate conversions between Puranic or classical Indian time reckoning and Western time. ${ }^{23}$ Switching to Madras Standard Time in I 86I implemented this early consciousness of the importance of the telegraph to a new conception of time. The Indian Telegraph Department switched to a continuous timescale, that is, calculating time not in terms of divisions of twelve but in terms of twenty-four. ${ }^{24}$ The increasing unification of the first electronic network had an immediate and fundamental urgent impact: ${ }^{25}$ at midnight on I July I 905 all telegraph clocks in India were synchronized. Greenwich Standard Time was introduced in India and Burma. ${ }^{26}$

In the reports from the local governments several notes of caution were sounded. MacLagan noted

[...] the apparent readiness of Calcutta but not of Bombay and Karachi to adopt the five and a half hour's standard [from Greenwich Mean Time] for local time [...] it appears that if the Standard Time is adopted in Bombay, Calcutta and Karachi, it will for all practical purposes be universal in India.

He suggested a vigorous campaign by the government through the introduction of Standard Time in post offices, schools, government offices, and the firing of midday guns. ${ }^{27}$ Denzil Ibbetson disagreed in his note and warned that any "appearance of trying to force the hand of the nonofficial community will do more harm than good". He pointed out that it was the Lieutenant Governor Sir John Fergusson's attempt to "hustle" the Bombay people by introducing Madras time in all government institutions that led to the failure of the experiment, and that most of the private sector and banking had kept to the local time. ${ }^{28}$

The city of Karachi managed to drum up public support from its local elites $^{29}$ but the Bombay business community presented a different case. The government of Bombay warned that though the "bulk of opinion" supported the replacement of Madras Time with Standard Time on

23. Kalidas Maitra, Electric Telegraph Ba Taritbartabaha Prakaran (Srirampur, I855), pp. I $50-$ I 53 .

24. Report of the Telegraph Department, I860-I86I, Appendix L, General Branch Circular no. 43, from Major C. Douglas, 6 September 186I. Extract from the periodical Once a Week for March I 86I, p. 273; NL.

25. Cf. Leonard Waldo, “The Distribution of Time”, Science, I: 23 (4 December I 880), pp. 277280 .

26. Department of Commerce and Industry [hereafter C \& I], Telegraph (A), August 1905, nos 20-25, Adoption of the Standard Time in India and Burma with effect from ist July 1905; NAI. 27. Department of Agriculture and Revenue (Revenue), Meteorology (A) Notes, June I905, nos 6-35; note by E.D. Maclagan 2I January 1905; NAI.

28. Ibid; note by Denzil Ibbetson, 22 January I905; NAI.

29. Ibid.; Proceedings no. 30; from the government of Bombay, no.135P, 26 June 1905 ; the Port Trust and the municipality of Karachi adopted resolutions in favour of the adoption of the Standard Time; NAI. 
railways and telegraphs, in the city of Bombay and in Karachi there was "a strong preference for Local Time". ${ }^{30}$ Protests started among workers, especially telegraph workers and postal deliverers who were first to be hit, along with the railway workers. However, railways were comparatively less affected, with an approximately eight-minute adjustment from their previous Madras Time schedule. The Bombay Samachar wrote in an editorial entitled "The unpopularity of the Standard Time with the masses" that the "government will earn the blessings of the native population by restoring to the City its old time". ${ }^{31}$ The postal delivery establishment in Karachi and Sindh complained in the press and through strike actions that the new railway schedules had forced them to do three deliveries a day when they had previously done two. "Owing to the change in the Railway Time-table [...] Posts have to be delivered thrice in stead of twice, yet there is no increase in the staff." ${ }^{2}$ Sporadic strikes began to break out in the public sector and in the mills. Bombay telegraph delivery staff went on strike to protest against longer delivery schedules, as well as to demand a special allowance to compensate them for the increases in price of basic necessities and the general cost of living in that city.

\section{REFORMS IN THE INDIAN TELEGRAPH DEPARTMENT}

In India the telegraph consisted of two broad branches: military and civil. The latter was further divided into the Telegraph Department, railway telegraph branches (increasingly managed by the Telegraph Department), and, in some areas, telegraph signallers attached to the Post Office. The Indian Telegraph Department also managed the the Indo-European Telegraph Department. This handled telegraph lines in southern Persia and Afghanistan, and was almost exclusively European. The Military Field Telegraph was established during I857 and continued as an integral element in British campaigns. Its signallers, usually British and European, were spread over the many military cantonments in India. Eurasians dominated in the staff of postal and railway signallers. Because the Indian Telegraph Department had been taking over these departments since i 874 , the few that remained as reserves were not really important until the strike. The Railway Mail Service had a significant number of Indian employees. The delivery and clerical staffs were a heterogeneous group including Eurasian and Indian Christian young adults from orphanages. It also

30. Ibid.; Proceedings no. 8; from the government of Bombay, no. 7148, 29 December 1904; NAI.

31. Bombay Samachar, 5 February 1907; Mukbbir-i-Islam, 4 Febrary 1907; Akbar-e-Saudagar, 5 February 1907; Report on Native Newspapers/Press [hereafter RNN/P], Bombay Presidency, no. 5 for the week ending 7 February 1907; Maharashtra State Archives [hereafter MSA].

32. Phoenix, I6 February 1907: RNN, Bombay, no. 7 for the week ending I6 February 1907; MSA. 
included a number of men from Bihar and Uttar Pradesh. Peons, who delivered messages, and clerks, who recorded, dispatched, and kept records and accounts, tended to be Bengalis and men from Madras, Pune, and Bombay.

Finally, the Indian Telegraph General Signalling establishment was mostly Eurasian and European in composition. A subsidiary local service existed and had more Indians on the rolls but they were not transferable. Open examinations were held at centres like Madras, Bombay, and Calcutta for recruitment of Indians into the Telegraph Local Service, who had little prospect of promotion to the senior grades. The Rourki Engineering College, for example, was important in training and educating Indians. This local service was increasingly made redundant while the general service was expanded. The general service departments were increasingly exclusive racial reserves.

There were two broad categories of workers that withdrew labour during the telegraph strike. There were the subordinate sections of clerks and peons, usually Indians. The delivery establishment had a preponderance of adult Indian male temporary employees, who sometimes had been in employment for over twenty years. They received very little wage increases, perks, pensions, or medical facilities, and because they were on a temporary or daily register their holidays were practically nonexistent. The clerks and peons were mostly Indian and Christian Indians. There were the signallers, of which 75 per cent were European and Eurasian in I 908.33 The haphazard Europeanization of the uncovenanted civil service in the 1860 s had serious consequences for the future. The rapid recruitment of telegraph staff in Britain between I866 and i87i meant that between 1903 and 1907 there would be almost forty retirements at a senior level and blocks in promotion plagued the telegraph establishment from the i 880 os.

To reconstruct the immediate and the general context of the Telegraph Strike of I908, conditions specific to the Indian Telegraph Department and the changing structure of technology and politics within which it was situated need elaboration. A brief note was circulated between the highest levels of the Telegraph Department and the government of India in I904. It was a prelude to the more public Telegraph Committee of 1906, and envisioned a drastic reduction in the staff of the Telegraph Department to improve efficiency, cut down on subordinate establishment costs, and allow for increased automation. The report reflected the need of the Telegraph Department to be competitive with the cable companies and maintain parity in rates. The size and the cost of the establishment were

33. However, such distinctions cannot be rigidly maintained for the course of the strike. For example, the Bengali signallers in the Calcutta Telegraph Office did not openly join the strike but the boy peons, often Eurasian, joined the strike of the peons and clerks. 
not proving viable. This combined with the need to keep increasing the number of users by cutting rates. The report proposed that an additional 20 per cent be added to the strength of the general service of the signalling branch through selection from within the service, and that they would receive a higher rate of pay. The conditions of general service were formulated as follows: (I) staff must be European and Eurasian; (2) they must be qualified in code and figure tests; (3) be liable for service in any circle; and (4) reversal to local service was possible and permissible at any time but would entail lower pay and fewer facilities. 34 The authors of the scheme designed an "overall reduction in establishment through new standards of work". However, they warned the government that it would take a "considerable number of years before the disappearance of the existing signallers is effected". ${ }^{35}$ As an immediate recruitment and retention measure they proposed that in addition to pay, "all European and Eurasian signallers, who compose 75 per cent of the total establishment [the total being 2,279 in British India and Burma in 1904], be granted free quarters or allowance in lieu". ${ }^{6}$ The "decentralization plan" would then lead to a saving in the clerical establishment that would reduce the budget cost to Rs 3,249, a saving of Rs I,4I 2. Over time more than a few livelihoods, especially in the subordinate sections, were to be lost. ${ }^{37}$

As a consequence of this plan, and of fears about their future, signallers and clerks began to combine towards a union. The Telegraph Association began to be organized and the movement for a subordinate relief fund was started. Within a few months of this, a further aggravating factor appeared. Alfred Newlands, the Traffic Manager brought from Britain to reform the Indian Telegraph Department, submitted his proposal for a series of reforms that would fundamentally change the department. There was already resentment in the department over the appointment of an outsider to reform the Indian Telegraph Department. Along with technical changes and increased efficiency tests, he also proposed twenty to twenty-four hours of work every thirty-two hours ${ }^{38}$ and eight- to eleven-hour night shifts. It should be remembered that the signallers worked nights and weekends and got leave infrequently. However, it would also appear that the strikes arose out of ignorance of the aims of the Department, and the Director General subsequently publicly clarified that the eventual average

34. GoI, Department of C \& I, Scheme for the Reorganization of the Indian Telegraph Department, J.H. LeMaistre, Officiating Under Secretary, Government of India, and I.C. Thomas, Superintendent of the Telegraph, and personal assistant to the Director General, Indian Telegraph Department, p. I2; Simla: government publication, I904; NAI.

35. Ibid., p. 29; NAI.

36. Ibid., p. I4; NAI.

37. Ibid., pp. I0-I I, 22; NAI.

38. [Confidential], Reorganisation of the System of Work in the Telegraph Department (Simla, I 908), p. 5, from the General Secretary, Telegraph Association, to Private Secretary to the Viceroy, Simla, 6 April I908; Minto Papers, National Library of Scotland, Edinburgh [hereafter NLS]. 
working hours would be eight hours every day of the week and a reduction of night work from eleven hours to eight. ${ }^{39}$ Sporadic strikes also began to break out in the public sector and in the mills.

The Telegraph Committee's Report, which was submitted in 1907, had some disturbing proposals. During its deliberations it received as many as eighty-seven joint petitions from the subordinate ranks of the establishment. To summarize the issues, clerks and peons wanted the same status as signallers with openings for induction into the signalling establishment. They demanded a provident fund and pension, along with a proposal for the formation of an all-India association for welfare and recreation. Better medical facilities and allowances for rises in the cost of living were included in their list of demands. They also protested against the prevailing system of financial penalties for mistakes and frequent transfers over long distances. Finally, revision in the scales of pay, promotion, and the department's policy on temporary employment, were key issues. Apparently the department had been using casual labour, and a clerk or peon could be classed as temporary for as long as fifteen or twenty years with no prospect of getting a pension or benefits. ${ }^{\circ}$ Nearly all the demands were refused. Attempts were made to amalgamate the post and telegraph departments and substantial reductions in the clerical and delivering establishment were proposed. ${ }^{4}$

The Telegraph Committee proposed to freeze recruitment and induct women, military signallers, and Eurasian and European youths from the orphanages and mission schools in India. They also quite frankly recorded their reservations against "smart" men from Calcutta, Bombay, and Madras. These standard pools of successful examination recruits were to be replaced by women and young recruits from the orphanages. The argument against the Bengali, "Bombayite" and "Madrasi" was that they might not be physically in shape for the task of touring and inspecting offices. Arbitrary fines, penal transfers, and temporary, unpensioned, and insecure employment were genuine grievances and had been admitted by the Telegraph Committee which wrote, "Not only is the organisation of the signalling establishment defective but the existing rates of pay are [...] inadequate." The Committee recorded that between May and October of I 906 alone as much as I8.5 per cent of the signalling establishment was transferred, often for very long distances. It stated that this percentage of transfer "practically amounts to the transfer of the whole staff of every office in three years". ${ }^{42}$

39. Ibid., p. 25 , from T.D. Berrington, Director General, Telegraph Department, to the Secretary, Department of Commerce and Industry, Kanpur, I० April ı908; NLS.

40. Report of the Telegraph Committee, 1906-1907, Appendix, Calcutta: Superintendent, Government Printing, 1907, pp. 86-90 [hereafter Telegraph Report]; CUL.

4I. Ibid., Summary of the recommendations of the Committee; CUL.

42. Ibid. 


\section{PREPARATIONS FOR THE STRIKE}

The telegraph workers' movement started with fresh impetus in November 1907 as rumours about the impending submission of the Committee's report began to circulate. Most of the establishment suspected the report to be unfavourable. It was reported in the press that "messages were exchanged between the signallers in all the main offices in India and a general assent was obtained from to concerted action [...] great excitement at Bombay, Calcutta, Karachi, Madras, Rangoon, Gauhati, Allahabad and other offices". ${ }^{43}$ So it was a process by which anonymous individuals tapping the telegraph keys became individual identities in order to coordinate and communicate between each other. The telegraph workers had to engineer a crisis of sufficient dimension to escape victimization and to underline their irreplaceability to the state and business. The volume of messages between telegraphers was growing and a different network and virtual community with its own politics and codes functioned within the telegraph network. Rangoon was one of the main coordination centres for the movement. The Director, Criminal Intelligence, reported to the government on the agitation amongst the subordinate staff and activity of the representatives of the Telegraph Memorial Committee at Rangoon in December 1907.

Henry Barton took the initiative for telegraph unionization in the autumn of 1907 . Barton was a senior employee having served twenty-six years in the service. Later, in the report to the Viceroy on Barton, the Director General of the Telegraphs explained Barton's motives away as pique at a missed promotion. During the same month Henry Barton was addressing telegrams on behalf of the Telegraph Association. ${ }^{44}$ These telegrams requested a reply to the general memorial and listed their grievances, which included protest against overtime. Above all they demanded the early publication of the Telegraph Committee's Report submitted in December 1907. From the start Barton was a problem for the government. He had none of the discretion essential in government service. In December 1907 or January 1908, Newlands met Barton in Burma while on tour as Traffic Manager. Barton brought along the local representative of the Telegraph Association to this meeting, who was on the staff of the Rangoon Times. The details of the interview were published in both the Telegraph Recorder and the Rangoon Times. A lecture delivered before the staffs by Newlands was similarly cited in detail in the same week in these publications.

The Director General, in his note to the government, saw this as a clear

43. The Panjabee, 7 December 1907, Centre for South Asian Studies, Cambridge [hereafter CSAS].

44. Department of C \& I, Telegraph Estab. (A), December 1907, nos I-I 5; NAI. 
breach of official etiquette if not actually of the Official Secrets Act. He held that Barton "was mainly responsible for the appearance of the communications". Moreover, Barton in his February 1908 address in Calcutta, "in contravention of the special orders, [...] read out a official communication which I had issued to the staff, and which was in consequence published next morning in the local papers". The government noted that he "did good work" in upper Burma, but this did not entitle him to any consideration in the eyes of the Telegraph Department. The Director General posted him from Rangoon to Berhampur. It was not a central location and Barton refused to go to Berhampur. Instead, he asked for a posting either in Rangoon or in Calcutta. Upon his request being turned down, Barton resigned in January 1908 and proceeded on a

[...] tour of the principal telegraph centres in India and delivered inflammatory speeches to the men. Owing to the fact that he possesses undoubted ability above the average of the ordinary signaller, and to the gift of delivering addresses, he has had great influence over almost the entire signalling staff. 45

Henry Barton, as Secretary to the Telegraph Association, began to publish the Telegraph Recorder from Rangoon in January $1908 .{ }^{46} \mathrm{It}$ is perhaps this early revolt against arbitrary transfers that allowed the movement to gain in coherence and organization.

The flows and eddies in information supplies crucially determined the chronology of events. The government declined to publish the Report. The Times of India complained, "although the Committee's report was delivered at Simla a year ago, the public know nothing of it". ${ }^{47}$ In February 1908 the entire staff sent identical memorials to the Viceroy. The government in reply stated that it adhered to its decision "not to publish the report of the Telegraph Committee until they have submitted their recommendations to the Secretary of State and his orders obtained there on [...]. Regarding the questions raised (by the petitioning workers) [...] the Government are at present unable to hold out any hope". ${ }^{8}$ The government of India was extremely sensitive to the press and had to be very aware of the language of its official publications, especially in the context of the growing heat generated in the British parliament on Indian affairs. The Telegraph Committee's report could not be published in the form it was submitted. The telegraph employees of Allahabad met on the

45. Ibid., no. 4, from the Director General, Telegraphs, to the Private Secretary to the Viceroy, no. 29-T, 29 April I908; NAI.

46. Sharma, Labour Movement in India, pp. 65-66.

47. Times of India, Bombay, 20 February I908: letter to the Editor; MSA.

48. Amrita Bazar Patrika, I 8 January I908, p. 5, NL; also Times of India, Bombay, 20 February I908; MSA. 
I9 January 1908 to agree to join the Subordinate Relief Fund, and significantly, "promising to enlist all absentees in the same cause". 49

The government of India was shocked at the sheer volume of messages that it was inundated with: II 6 identical memorials were sent to the Viceroy on one day from the signal room clerks in the Bombay Division alone. ${ }^{\circ}$ Many sections among the clerks, signallers, and peons coordinated to achieve this effect. Waves of petition followed with growing concentrations from December 1907 up to February 1908. ${ }^{\text {II }}$ In January the entire signalling staff of India and Burma sent in almost identical petitions to the Viceroy..$^{22}$ The government was also surprised by the fact that the petitions poured in from different parts of the system. Nagpur, Bombay, and Karachi clerks experimentally coordinated to be received on the same day. Nagpur sent its petitions on the 8 February, ${ }^{53}$ as did Karachi, ${ }^{54}$ while Bombay had sent its petitions two days earlier on the 6 February. 5 An infuriated Director General lashed out in his report to the government at the problem of "surplusage of temporary clerks", and commented on the identical nature of the submissions, that the "generality of the prayers made are such as to court refusal" [italics mine]. ${ }^{56}$ The Director General pointed out, "as a rule they [the clerks] are not up to the required standard of education, and it is most undesirable that a clerical post should ever get to be looked upon as a stepping stone to the Signalling Establishment".57

\section{THE STRIKE OF THE PEONS}

On the night of Thursday 27 February 1908, the delivery peons of the Telegraph Department struck work. There had being growing discontent as new methods of delivery and attendance were introduced over December and January. Barton, General Secretary of the Indian Telegraph Association, asked for public sympathy and support from the press. ${ }^{8} \mathrm{He}$ urged the workers to adopt constitutional means of action. ${ }^{99}$ By Saturday

49. Amrita Bazar Patrika, 22 January I908, p. 9; NL.

50. Department of C \& I, Telegraph Estab. (A), nos 7-I0, February I907; NAI.

5. Ibid., nos I-I 5 , December 1907; NAI.

52. Ibid., nos 27-29, January 1908; forwarded with report from the Director General; NAI.

53. Ibid., nos 7-10, February 1908, no. 8, from Nagpur; NAI.

54. Ibid., no. 9, from Karachi; NAI.

55. Ibid., no. 7, from Bombay; NAI.

56. Ibid., nos I 8-20, January 1907; NAI.

57. Ibid., no. I 8, from Sir Sydney Hutchinson, Director General of Telegraphs to the Secretary, Government of India, Department of Commerce and Industry, is December 1906; NAI.

58. Times of India, 2 I February 1908; MSA.

59. Amrita Bazar Patrika, 28 February 1908, p. 5; NL. 
the entire system of delivery in Calcutta appeared threatened. Initially I 73 permanent and 193 temporary men went on strike. Their numbers swelled and almost 400 men were involved. The striking workers met at the Calcutta maidan, beneath the Ochterlony monument, and held a meeting adopting resolutions. This echoed the methods adopted by political parties across the spectrum. It was as much a protest action as it was a publicity stunt; the striking workers chose one of the oldest and most familiar locations for political speeches and meetings. They demanded the same wages as the Bombay staff, better hours and conditions of work, winter clothing, batta [cost of living allowance], and promotion according to seniority regardless of temporary or permanent positions, and, most provocatively, the reinstatement of the two peons dismissed from service as the ringleaders of the 1907 strike in Bombay. ${ }^{60}$ As mentioned before, the Bombay post and telegraph delivery establishment had struck work over the new delivery schedules and their demand for an allowance to meet the sharp rise in the general cost of living in that city.

That there were wider issues and feelings involved is shown by the fact that by Monday 2 March, the boy peons at the Calcutta Central Telegraph Office, numbering about ı०o, joined the strike. These were probably Eurasian and Indian Christian orphans aged between sixteen and eighteen. ${ }^{61}$ Madras telegraph peons, numbering around sixty, went on strike on 4 March. ${ }^{62}$ Telegraph Delivery peons in Bombay followed suit on the 29 March in spite of the concessions they already enjoyed because of the strike in $1907 .{ }^{63}$ These latter two were largely Indian. The Post Office clerks sent a petition threatening to join the strike. ${ }^{64}$ The postal workers in Modassa, Ahmedabad, joined in the movement. ${ }^{65}$ The same day, the clerks at the Accountant General's Office threatened to strike work. ${ }^{66}$ Everywhere around them there were workers striking: in mills in Tuticorin, 2,000 men in the marine dockyard in Khidirpur in Calcutta, in jute mills in Chandernagar, 6,000 workers at the railway workshop at Parel in Bombay. The Railway Mail Service was dismantling the railway and mail schedules. Letters were written to the press against the actions of the Inspector General, Railway Mail Service. ${ }^{67}$ The labourers employed to look after the

\footnotetext{
60. Ibid., 29 February 1908, p. 7; NL.

6r. Ibid., 2 March I908, p. 4; NL.

62. Ibid., 6 March I908, p. 8; NL.

63. Department of C \& I, Telegraph Estab. (A), nos 3-8; administrative report of the Indian Telegraph Department for 1907-1908 with notes; Gujarati, 5 April 1908; NAI.

64. Amrita Bazar Patrika, I 3 March 1908, p. 6; NL.

65. Mabi Kantha Gazette, 8 March I908; RNP, Bombay, no. I , for the week ending I 4 March I908; MSA.

66. Amrita Bazar Patrika, s March i 908, p. 6; NL.

67. Ibid., 25 February 1908, p. 7; NL.
} 
overhead lines in the Calcutta Tramway Company struck work; they were dismissed overnight. ${ }^{68}$ In short, in 1907-1908 many of the branches of the administration seemed to be on the verge of open revolt. The strikes ended suddenly: the boy peons and the delivery peons and clerks were summarily sacked, ${ }^{6}$ and the Ioth Jat regiment was deployed for the delivery of messages until a new establishment was employed. $7^{\circ}$ Peons were brought in from Jullunder and Delhi. ${ }^{71}$ The striking workers showed precocity in their demands, organization, and solidarity in different parts of the country. Their method and strategies were mature. They sent a petition to the Commissioner of Police requesting him to intercede with the Director General and the Superintendent of the Telegraph Department on their behalf or accept their resignations. Here they stressed the loyal and peaceful nature of their rally. They "wished to hand over their badges and uniforms to the Commissioner of Police and requested him to get their dues from the Department". ${ }^{22}$

The peons showed both organization and courage. The workers combined in Calcutta, Bombay, Karachi, and Madras to go on strike on both general and specific demands. The majority of these were Indian workers. Their willingness to sacrifice their jobs showed increasing politicization in their ranks. Ultimately they were replaceable, yet with the help of the media and possibly interoffice communication through some of the signalling staff, they combined across centres to provide the spark for the signallers' strike. The number of strikes breaking out demonstrates sympathy existing horizontally and vertically across different types of administrative labour. These were the delivering and maintenance sections crucial to the functioning of state administration, communication, and business, yet they were at the fringes of the city spatially and socially, and acted simultaneously with other wage labour such as millhands. In the case of these wageworkers the media played a crucial role by reporting workers' actions in different centres, facilitating sympathy strikes. However, within each centre the worker also stood united with wageworkers in other industrial sectors. Significantly, the signallers sympathized with them, and it is this gesture of sacrifice and valour without any hope of success that possibly goaded the salaried workers to strike.

70. Department of C \& I, Telegraph Estab. (A), nos 3-8; administrative report of the Indian Telegraph Department for 1907-I908 with notes, p 4; NAI.

7I. Ibid., no. 20; demi-official from G. Rainy, Under Secretary, Government of India, to T.D. Berrington, Director General, Telegraphs, Tel. no. 2522, 9 March I908; NAI.

72. Amrita Bazar Patrika, 6 March 1908, p. 8; NL. 


\section{THE STRIKE OF THE SIGNALLERS: “PASSIVE RESISTANCE”,}

A month after the strike of the peons was broken, Alfred Newland, the Traffic Manager imported from Britain, launched a scheme of work shifts for signallers, which was implemented in all offices on 3 April 1908. The Statesman reported a heavy accumulation of messages in Burma, while the Bandemataram discussed the warning issued by Director General Berrington which pointed out that the rate of sending was being purposely and wilfully slowed down and "faults on wires and apparatus are also abnormally high". It was reported that "large numbers of men in Rangoon and Mandalay had reported sick". ${ }^{73}$ Throughout March the government had been occupied with the dismissal and re-employment of the delivery establishment at some of the vital centres of commerce and communication. The last batch of dismissed Bombay peons handed in their uniforms and collected their dues on 6 April. ${ }^{74}$

By 8 April 1908 the system was in the throes of the second crisis. The main wires were fused and rendered dysfunctional. Either engineering electrical faults or persons literally fusing the wires did this. On 6 April, fifteen trunk lines went out of order in Calcutta. Bombay had huge accumulations of messages, and two lines between Bombay and Madras were handed over to operators of the Eastern Cable Company, almost exclusively British and trained at Porthcurno. These operators showed that the lines were working and demonstrated that the signallers in the rest of India were "slacking off". The Calcutta office staff insisted that it was Rangoon and Bombay that held them up; Rangoon was commonly believed to be the source of the trouble..$^{5}$ It was reported that Madras was coping but Bombay, Calcutta, Rangoon, Agra, and Karachi were "affected". Lahore soon joined their ranks. ${ }^{76}$

The Empire thundered, "the operators are fooling [...]. They waste their time in keeping the offices informed of the accumulation of messages, discussing the situation and sending wires at different centres giving accounts of the Press attitude." 77 The Rast Goftar joined in the criticism. ${ }^{78}$ Tilak's Kesari wrote that while the "signallers who had gone on strike are mostly Eurasian and European [...] they have our sympathy. It is a little curious, however, that strikes undertaken by white employees are always successful, while those organized by native subordinates fall through."79

73. Bandemataram, 6 April I908; NL.

74. Ibid., 7 April I908; NL.

75. Ibid., 8 April I908; NL.

76. Ibid., 9 April I908; NL.

77. Reprinted; Ibid., 8 April 1908; NL.

78. Rast Goftar, I9 April I 908; RNP, Bombay, no. I6, for the week ending I 8 April I908; MSA.

79. Ibid., Kesari, i 4 April I908; MSA. 
Another main wire was found fused in the Calcutta office by noon on ro April. By now 8,000 messages were delayed and the figure was growing. The Director General issued a fresh circular, reminding the staff of the circular of 22 February and demanding "loyalty and good sense". Superintendents of Rangoon, Calcutta, Bombay, Agra, Lahore, Karachi, and other offices facing similar problems were given the power to dismiss arbitrarily up to ro per cent of the signalling staff.

As early as February, the Bengal Chamber of Commerce had warned the government, referring to the discontent in the subordinate ranks and had suggested "an enquiry into their [the workers'] alleged grievances with a view to avert a strike and the consequent disorganization of public business" ${ }^{80}$ Officials thought this blatant impertinence on the part of the Chamber. In his note on the letter, G. Rainy wrote that the Chamber's suggestion was "quite unreasonable and unintelligent $[\ldots]$ they are not in a position to advise Government. Their action can only be described as most unfortunate and tending directly to the encouragement of insubordination amongst the men." ${ }_{1}$ The Viceroy, Lord Minto, commented that "the Chamber of Commerce letter was most ill-judged and unjustifiable". ${ }^{82}$

In its reply to the Chamber's letter, the government stated that the difficulties were being removed by (I) introducing reforms of a radical nature in the working of the Department, and (2) improving conditions of service of the subordinate staff. The government also categorically stated that it did not apprehend a general strike of the signallers. ${ }^{83}$ The Marwari Chamber of Commerce received a much more terse reply to its letter of Io March. ${ }^{8}$ The Chamber had complained of the "Indian merchants and traders who have suffered and are still suffering considerable loss and inconvenience through the phenomenal delay because of the strike of the delivery peons" ${ }^{85}$ The Anglo-Indian papers pointed out that "Trade and commerce everywhere throughout India is in a state of paralysis, and our happy-go-lucky Viceroy is away enjoying himself shooting tigers, apparently not caring a tuppenny damn whether the commerce of India goes to the devil or not." 86

The Bengal Chamber of Commerce appealed to the Viceroy on 7 April

80. Department of C \& I, Telegraph Estab. (A), March 1908, nos I8-25, no. I8; from the Secretary, Bengal Chamber of Commerce, no. 296, 26 February I 908; NAI.

8I. Ibid., March 1908, no.19; note by G. Rainy, 3 March 1908; NAI.

82. Ibid., March 1908, no. 19; notes by Harvey and Minto, 7 March 1908; NAI.

83. Ibid., March 1908, no. 20; to the Secretary, Bengal Chamber of Commerce, no. 2544-59, I0 March i 908 ; NAI.

84. Ibid., March 1908, no. 23; to the Secretary, Marwari Chamber of Commerce, no. 3208-59, 26 March I908; NAI.

85. Ibid., from Secretary, Marwari Chamber of Commerce, no. 59, 26 March i 908; NAI.

86. Oriental Review, RNP Bombay, for the week ending Is April I908, reprinted from Max's column in the Capital; MSA. 
to appoint a Conciliation Board as had been done in the case of the railway strike in 1906-1907. This strike had paralysed transport and commerce but, with strong lobbying from the Bengal Chamber of Commerce, it had a relatively quick solution. The Viceroy's Personal Secretary telegraphed a reply that refused viceregal intervention and was a tirade against the staff who have "chosen to deliberately block the introduction of the new hours of duty by delaying messages and absenting themselves from duty". ${ }^{87}$ The workers used what they and the government called the strategy of "passive resistance": slowing down of work speed, engineering faults, and collective absence at work through medical certificates and other forms of legal leave, leading to accumulation of messages on most of the major Indian lines. Pile-ups meant delays, not immediate disruption. Delay meant that the unified world time and the emerging global market were in jeopardy. The primary difficulty faced by the administration was the fact that, this being a system of electronic communication, it was more concerned with transmission and motion than with posts and stations. The workers could delay the system considerably yet blame the next station and it was difficult in an emergency to pinpoint the exact source of the accumulating information snowball; delay, in this case, was cumulative. This element of surprise was removed when the workers went public with their demands. The realization of this strategy dawned on the government slowly as it became aware that there were too many accidental breakdowns, absences and pile-ups to be a coincidence.

Henry Barton, Secretary to the as yet unrecognized Telegraph Association, addressed a large meeting in Rangoon towards the end of April 1908. The Director General of the Indian Telegraphs issued a threatening circular in response that the Rangoon Times called an "egregious blunder". The Director General's circular prohibited the further use of the workers' club premises for meetings, threatened dire punishment for attendance "where such language was used", and warned the signalling staff that "unauthorized publication of information obtained officially" would render them liable to prosecution. ${ }^{88}$ This was reported by the local press along with the government's refusal to countenance a provident fund for the subordinates, arguing that it was too close a copy of the privileges of the superior establishment. ${ }^{89}$ A number of letters began to appear in newspapers complaining of the plight of the clerks, signallers, and delivery service, and citing unhappy work conditions as the reason for

87. Ibid., I 2 April 1908; MSA.

88. Department of C \& I, Telegraph Estab. (A), no. 4; from the Director General, Telegraphs, forwarding with his remarks the memorial addressed by Henry Barton, late Telegraph Master, no. 29-T, 29 April I908; NAI.

89. Amrita Bazar Patrika, 2I February 1908, p. 9; NL. 
the prevailing mismanagement..$^{\circ 0}$ The Bengal Chamber of Commerce and the Calcutta Trades Association voiced criticism and concern. ${ }^{9}{ }^{\mathrm{I}}$ The Director General of the Telegraph, T.D. Berrington, agreed to meet the representatives of the Chamber of Commerce in secret; "the Director General stipulates that no reporters are to be present and that no report of the meeting will be published in the newspapers". The negotiations were conducted over the telephone..$^{2}$ As soon as the government's reply reached the staff through the Chamber of Commerce, Rangoon declared the strike. Discontent was reported among the signallers in Chittagong. ${ }^{93}$ The Statesman reprinted a telegram from Barton announcing the strike in protest against the summary dismissals from the staff at Rangoon. ${ }^{94}$ The Director General summoned Barton from Rangoon to Calcutta. Upon his landing, Barton addressed a large gathering at the Town Hall.

\section{STRIKE AND PANIC}

The signallers went on strike in shifts so as not to lose out on their day's pay. The signal "Diabolic I5" was flashed to all the offices. It meant "general strike at $3 \mathrm{pm}$ ". A detailed description of the strike in Calcutta is available in the Bandemataram. The first batch struck in Calcutta at three in the afternoon. "The new watch and the old watch gathered on the steps and beckoned those inside to come out by waving sticks, hats and handkerchiefs. Two Eurasian youths, no doubt in their excitement, yelled the fatal word 'strike'." 95 In Bombay they began at $2 \mathrm{pm}$. Agra joined at 4. Kanpur and Allahabad were rumoured to be ready to strike at 5 in the evening. In fact, Allahabad joined the following day. In Bombay, twentyfive signallers were served with notices of summary dismissal. The notices were dated 8 April 1908. In short, there seemed a genuine possibility of a "general strike by the signallers throughout the country". ${ }^{96}$ Asked by the Bandemataram reporter whether the strike would be "universal", a spokesman for the strikers said that some of the senior men, while in complete sympathy, would not join the strike and that these men would be of use in keeping open communication between the different centres. $\mathrm{He}$

90. e.g. Ibid., 25 February 1908, p. 7, letter to the editor from a Railway Mail Service sorter; ibid., 27 February 1908, p. 10, letter to the editor accusing the Inspector General of degrading behaviour, arbitrary fines, and penal transfers of subordinates for trivial offences, from a "sufferer"; NL.

91. Times of India, 3 March 1908; MSA.

92. Department of C \& I, Telegraph Estab. (A), no. 20; demi-official from G. Rainy, Under Secretary, Government of India, to T.D. Berrington, Director General Telegraphs, tel. no. 2522 , 9 March i 908 ; NAI.

93. Bandemataram, I3 April 1908; NL.

94. The Statesman, Calcutta, I 2 April I908; NL.

95. Bandemataram, I3 April I908; NL.

96. Times of India, 3 March 1908: memorial by the Bombay Chamber of Commerce; MSA. 
added that the 60 Bengali signallers, out of a total of 240 in Calcutta, would not "by any chance go on strike". 97 By December 1907 reports had circulated in the press regarding discontent among Indian signallers who were discouraged to enter "general service" with its better pay and prospects. It was alleged that the "department was closing its doors to Indians". ${ }^{98}$ In the meanwhile, they could help keep communications open.

Large batches of postal signallers and military telegraphers were deployed to replace the striking workers. Burma was particularly hard hit because it had very few postal and military reserves. The main line often could not be operated. Another crucial problem was the new high-speed "Baudot" signalling instruments recently introduced on the main routes and in the main centres. The substitute signallers, so technologically out of touch that some of them had not tapped a key in the past three years, were rarely found to possess any working knowledge of the sophisticated Baudot.99 Thus, replacement of the strikers by sufficient numbers of efficient workers proved impossible. The Superintendent of the Agra office was removed; he had panicked and contacted the Deputy Superintendent of Police, who reported that,

The unrest among the telegraph clerks has extended to Agra, which is the biggest telegraph office after the three great centres of Calcutta, Madras and Bombay [...]. However, Mr Morgan [Superintendent, Telegraphs] was unnecessarily alarmed. [...] I send this by letter, and have not wired, as it is not desirable to attract more attention to the matter than is absolutely necessary and which would be the case if I sent long cypher wires under the present circumstances through the local telegraph offices [emphasis mine] [...]. The attitude taken up is obviously one of passive resistance and has taken the form of getting "sick" [...] at present the strike is not apparent to anybody unconnected with the with the Department.

He went on to add that Morgan had "panicked". ${ }^{100}$ The quandary of the government in having to avoid its main means of communication multiplied its feeling of panic and vulnerability.

The Telegraph Department resorted to the omission of the date of despatch from the telegrams so that receivers could not be sure of the time and date of despatch. This compounded the confusion. The Indu Prakash wrote in its columns,

[...] we have before us a telegraphic press message, which bears neither the date of despatch nor the timing. While we can suppose that hours and minutes have been

97. Bandemataram, I3 April I908; NL.

98. The Panjabee, Lahore, I I December 1908; RNP, Punjab; Seeley Library, Cambridge [hereafter SL].

99. Department of C \& I, Telegraph Establishment (A), December I908, nos I-3, Orders of the government of India on the memorials addressed to the Viceroy by the signalling staff; NAI. Io0. Ibid., August 1908, no. 5; extract from the fortnightly report, commissioner, Agra, 7 April I908; NAI. 
ignored in the hurry and confusion obtaining at present, it is difficult to ascertain why there is no room for the date of the message [...]. And in all business matters a good deal depends on knowing the date. ${ }^{\text {IOI }}$

\section{The Sind Gazette added,}

To all appearances there is a complete breakdown in the telegraph service between Calcutta and Karachi and a partial breakdown between Bombay and Karachi. Telegrams are filtering through slowly and, in the absence of any date of despatch, it is impossible to say whether the messages were despatched on the day of receipt or on the previous day or a week before that. ${ }^{102}$

Similarly, "at all the main centres efforts are being made to show a clean slate [...] sub-offices are being shut down and men are being drafted in post-haste from the mofussil". ${ }^{103}$ The disappearance of date and time of despatch from telegrams seemed to threaten the very basis of the need for rapid communication. Marwari merchants were complaining bitterly at the delay in the opium despatches. The government of India was forced to issue a notice in the government Telegraph Gazette refusing to accept ordinary and deferred telegrams at their telegraph offices until further notice. Telegraph offices were accepting only the very urgent ones at double the price.

Henry Barton was once again summoned to Calcutta from Rangoon. W.L. Harvey, Secretary, Department of Commerce and Industry, wanted officially to meet Barton, Secretary to the Indian Telegraph Association. This was the political breakthrough that the strikes had aimed for. Barton met Harvey as the representative of an officially recognized organization and "an amicable resolution was expected". ${ }^{104}$ The government of India announced an approximately 20 per cent rise in pay for the subordinate grade staff. ${ }^{\text {Ios }}$ The official strike ended twelve days after it had started. Speaking to the Rangoon Telegraph Association in I909, Barton described the "history and spread of the Association during the past eighteen months" and advocated as their motto "Definite Forwardness". ${ }^{106}$ On 22 April I908 wires were sent to all the centres in Burma and India announcing the return to work. Barton expressed his gratitude for the support of the press and the Chambers of Commerce. ${ }^{107}$

ıог. Indu Prakash, Bombay, 7 April 1908, Eng. cols; RNP Bombay, no. is for the week ending i April rgo8; MSA.

102. Sind Gazette, 3 April 1908; RNP Bombay, no. I 5 ; MSA.

103. Sanj Vartaman, I6 April 1908; RNP, Bombay, no. 16 for the week ending I 8 April 1908; MSA.

104. Bandemataram, i9 April 1908; NL.

105. Department of C \& I, [Confidential] Reorganisation of the System of Work, p. 29, from the Secretary of State to the Viceroy, I3 April 1908; NL.

I06. Amrita Bazar Patrika, 4 June 1909, p. 4; NL.

107. Bandemataram, 22 April 1908; NL. 


\section{CONCLUSION}

The workers had struck work over the government's refusal to publish the Telegraph Report. An obsessively secret bureaucracy generated its own scares and panics with an over anxious surveillance and policing. A strike at the centre of the communication system increased its sense of panic. The government could not communicate while the system to do so was in revolt. This was the second mutiny so anxiously looked for by the government yet completely surprising and paralysing when it happened. The telegraph strike over the summer of 1908 reveals that there was a perception of unity, as the workers withdrew labour at around the same time in different centres. The strike was not a Luddite, millenarian, or communitarian uprising but one that was integrally linked to the world economy and technological change. It involved European, Eurasian, and "up-country" men, Bengali clerks, and maintenance staff. Traditional means of ethnic, racial, and caste enumeration are possibly inadequate to describe the workers involved. The victory of the signallers had as its underbelly the sharp polarization between Indian, Eurasian, and European workers. It was the direct experience of state repression and representational politics of the time that led to the subsequent hardening of community identities among the workers. The Eurasian and European signallers were re-employed if they agreed to try out the new working system and hours. Though many requests were made to re-employ the dismissed peons they were not taken back. ${ }^{108}$

The experience of 1908 and after showed how a high degree of organization and mutual sympathy could crumble without a platform. The Telegraph Association was both a symbol and a platform for the unity of signallers, and in this the Chambers of Commerce helped them. The peons and clerks had no similar organization that could give coherence to a sustained campaign. However, these experiences allowed the political process and the system of government to be understood. In contrast, the European and Eurasian workers had to be unequivocal about their patriotism and loyalty to the Empire and government and promise not to strike. Henry Barton, as Secretary of the Telegraph Association, publicly protested that the "movement was free from anything approaching insubordination or disloyalty". ${ }^{1 \circ}$ In the end it was both a failure of representation and an inability to avoid unionization that led to the abandonment of broader political ambitions and the crossclass cooperation of the strike. The emergence of community and racial identity in the process of working-class unionization reflected on a smaller scale the partial democracy, the form of political or rights representation, and the communal award system soon to be introduced at an all-India level. 
Henry Barton was imprisoned as a pre-emptive measure by the government under the Defence of India Act passed after the outbreak of World War I. The government was not prepared to risk jeopardizing its main communications. After the War, the Telegraph Committee of I920I92 I was formed to look into the petition sent by Barton, once more General Secretary of the Indian Telegraph Association after his release from prison. This was after a large revision in pay scales and organization had been implemented in I919. The revisions came from the proposals of two different committees: the first looking into the affairs of the Post Office and the other into the Telegraph Department. The government's anxiety to address workers' issues and concerns contrasted vividly with the attitude of the state slightly more than a decade ago. The Committee's

$[\ldots]$ anxiety was to arrive at a decision which should satisfy reasonable men [...]. The Government has already incurred an additional expenditure of nearly 32 lakhs per annum since November 1919 over this [Telegraph] Branch and another I 30 lakhs per annum on the Postal Branch. These proposals are likely to make a substantial addition. It is now up to the men to combine to respond loyally to this generous treatment. ${ }^{\text {IIO }}$

While greater articulation and confidence can be seen in the demands of the workers, there was a growing tendency to encourage factional representation. Thus, telegraph signallers, inspecting staff, and clerks were invited to petition separately. ${ }^{\text {II I }}$ The state's interest in dealing with factions and fragments was clear, and at one point Barton's petition argued against the divisive policy adopted by the government which was dealing with about roo senior temporary clerks on a piecemeal, individual basis. The issue was the transfer of slightly over half into permanent positions but again dividing them by giving some a time-scale salary while others got fixed increases. ${ }^{112}$ Yet the workers too showed increasing factionalism and Barton, sitting with government nominees on the Committee, held forth against the "outsiders" and women who were employed at the cost of permanent staff, especially on telephone duty. ${ }^{\mathrm{II} 3}$

The transregional economic general strike of 1908 in India was remarkable because of the workers' ability to use the telegraph to coordinate and organize. Flooding the government with petitions from different centres and in huge quantities demonstrated the new weapons forged by the workers, with a consciousness of themselves as a larger entity beyond the immediate neighbourhood or region. The government's inability to deal with this shows how startling were the methods forged by the first virtual community through and because of the telegraph, that held

I 10. Report of the Telegraph Committee, I920-192I, Simla, I92I, P.I3; NL.

I I I. Ibid., Annexure; NL.

I I 2. Ibid., pp. 5-7; NL.

I I3. Ibid., p. I7; NL. 
the attention of business, state, and media simultaneously. An industrywide strike was achieved involving vertical as well as lateral cooperation, and the telegraph and media were used to organize strikes at the same time in different centres. The study of general strikes in India in the social and political sense has led to a concentration on the spaces and associations of mobilization that included teahouses, messes, native place and caste associations, and the mohalla or neighbourhood. ${ }^{I 4}$ However, these networks were not primary or crucial in the case of the telegraph strike; combining across regions and cities meant the neighbourhood had little significance. The emergence of community and racial identity in the process of working-class unionization thereafter reflected upon a smaller scale the partial democracy and communal award system seen at all-India level. Increasing factional representation yet growing horizontal coordination after 1908 contrasts with the case of monopoly capital, which saw large centralized unions in the US. ${ }^{\text {II }}$

Alongside the specific demands of the workers, there were more universal and general demands, echoing labour movements across the world. The universal standardization of time and the changes proposed in work-hours reflected an international concern of information labour. In 1907, the telegraph workers struck work in the USA. The Indian press reported in August 1907 that there was a "great strike of telegraphists [...] over I600 operators in Chicago, sympathetic strikes in Denver, Colorado, and Salt Lake City [...]. The telegraphists strike has spread to 50 cities in the western and southern States." "I6 It was reported that Toronto and Montreal had joined in the strike and that "communication has stopped throughout the USA except by telephone". ${ }^{117}$ In the US, perhaps more so than in India, the strike of 1907 was successful in scale but tragic in consequence. After 1907, messenger boys were absorbed in general unions and made irrelevant in the media, ${ }^{118}$ and signallers were rapidly replaced by automation and women; neither could maintain their positions within the industry. ${ }^{19}$

Downey's argument about the agency of telegraph delivery boys is borne out in the Indian strike: in India, peons, clerks, and delivery staff were the catalysts that precipitated the signaller strikes. This does not

I I4. Bryna Goodman, City and Nation: Regional Networks and Identities in Shanghai I8331937 (Berkeley, CA, 1989); R. Chandavarkar, The Origins of Industrial Capitalism in India: Business Strategies and the Working Classes in Bombay, 1900-1940 (Cambridge, 1994).

i s s. Cf. C. Craypo, "The Impact of Changing Corporate Structure and Technology on Telegraph Labor, I 870-1978”, in idem (ed.), Labor Studies Journal, pp. 283-304.

i 16. Amrita Bazar Patrika, I4 August 1907; NAI.

I 17. Ibid., i7 August 1907; NAI.

II 8. Downey, Telegraph Messenger Boys, pp. I73-174, I77.

I 19. Craypo, "Impact of Changing Corporate Structure and Technology on Telegraph Labor", pp. 294-295. 
mean that they were successful; the signallers because of their organization were able to historicize their action and get their own union. The peons and clerks, mainly Indian, achieved this in the I920s through, in part, the leadership of union leaders like Tarapada Mukherjee. Thus, even though the delivery boys, peons, and clerks were the agents/catalysts of the strike, they did not have the agency to realize their political objectives. Ironically, unionization allowed workers to articulate a history and process though sacrificing spontaneity and broader working-class unity. The unionization that occurred under the patronage of the middle class, for example on the railways in India, was Masonic. ${ }^{\mathrm{I} 20}$ In the Indian case, the delivery and clerical staff were heterogeneous and perhaps did not have the same iconic connotations that they had in the US. The majority was Indian, male, mainly adult, and usually temporary. Though in places like Calcutta and Bombay young boys were employed, they did not constitute a majority or significant agency. In India, subordinate unionization across different communication industries was realized after the first two decades of the twentieth century. The suggestion that the messenger boys were enmeshed with the survival of the industry in the US is provocative: ${ }^{\mathrm{I} 2 \mathrm{I}}$ perhaps the associations of the mass of subordinate delivery workers and various grades of signalling staff in India after 1920 and the telegraph as a government-run public utility contributed to the telegraph being a living reality in India.

I 20. This possibly happened in the US telegraph unionization of the r880s; cf. Gabler, The American Telegrapher, p. I88.

I2 I. Downey, Telegraph Messenger Boys, p. 202. 